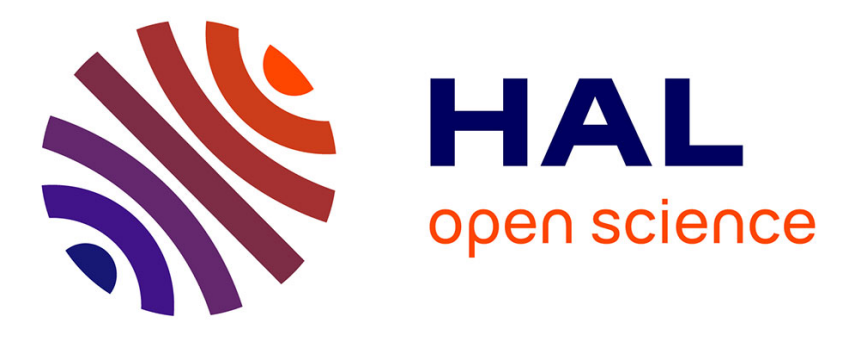

\title{
Cellular therapy treatment of chronic radiation cystitis in rats
}

Clement Brossard, Morgane dos Santos, Christelle Demarquay, Valerie Buard, Georges Tarlet, Claire Squiban, Christine Linard, Noëlle Mathieu, Romain Granger, Amandine Sache, et al.

\section{To cite this version:}

Clement Brossard, Morgane dos Santos, Christelle Demarquay, Valerie Buard, Georges Tarlet, et al.. Cellular therapy treatment of chronic radiation cystitis in rats. International Society Cell and Gene Therapy, ISCT 2020, ISCT, May 2020, Paris (virtual), France. pp.71, 10.1016/j.jcyt.2020.03.111. hal-03431754

\section{HAL Id: hal-03431754 https://hal.science/hal-03431754}

Submitted on 16 Nov 2021

HAL is a multi-disciplinary open access archive for the deposit and dissemination of scientific research documents, whether they are published or not. The documents may come from teaching and research institutions in France or abroad, or from public or private research centers.
L'archive ouverte pluridisciplinaire HAL, est destinée au dépôt et à la diffusion de documents scientifiques de niveau recherche, publiés ou non, émanant des établissements d'enseignement et de recherche français ou étrangers, des laboratoires publics ou privés. 


\section{Cellular therapy treatment of chronic radiation cystitis in}

\section{rats}

Clément Brossard ${ }^{1}$, Morgane Dos Santos $^{2}$, Christelle Demarquay ${ }^{1}$, Valerie Buard ${ }^{1}$, Georges Tarlet $^{1}$, Claire Squiban ${ }^{1}$, Christine Linard ${ }^{1}$, Noëlle Mathieu ${ }^{1}$, Romain Granger $^{3}$, Amandine Sache ${ }^{3}$, Delphine Denais Lalieve $^{3}$, Fabien Milliat ${ }^{1}$, Alain Chapel $^{1}$

${ }^{1}$ : Institut de Radioprotection et de Sûreté Nucléaire (IRSN), PSE-SANTE, Service de recherche en radiobiologie et en médecine régénérative (SERAMED), Laboratoire de Radiobiologie des expositions médicales (LRMED), Fontenay-aux-Roses, France

2: Institut de Radioprotection et de Sûreté Nucléaire (IRSN), PSE-SANTE, Service de recherche en radiobiologie et en médecine régénérative (SERAMED), Laboratoire de radiobiologie des expositions accidentelles (LRACC), Fontenay-aux-Roses, France

${ }^{3}:$ Institut de Radioprotection et de Sûreté Nucléaire (IRSN), PSE-SANTE, Service de recherche sur les effets biologiques et sanitaires des rayonnements ionisants (SESANE), Groupe de support à la recherche et à I'éthique animale (GSEA), Fontenay-aux-Roses, France

\section{Correspondent's e-mail address: clement.brossard@irsn.fr}

\section{Bacgrounf and aim}

Chronic radiocystitis ( $\mathrm{CRC}$ ) is a pathology resulting from irradiation of the pelvic area without long term effective treatment. CRC is characterized by chronic inflammation progressing to fibrosis, fistulas and cystectomy in the most severe cases. Our laboratory have previously demonstrated that MSC treatment reverse similar damages in irradiated colon. Furthermore in a clinical phase 1/2 treatments using MSCs for hemorrhagic cystitis, which is pathology similar to CRC, was sucessfull (Ringden O et al., 2007). Based on these previous results, our objective is to evaluate whether adipose derived mesenchymal stem cells (MSCs) could be an innovative treatment of CRC.

\section{Methods, results and conclusion}

Preclinical modeling of CRC in rats (Sprague Dawley) was established by irradiating the entire bladder with a single dose of 40 Gray using the Small Animal Radiation Research Platform (SARRP, figure 1)). At four months afterirradiation, animals received a treatment consisting in tree intravenous injections of 5 million of MSCs every two weeks. After irradiation and treatment, a physiological, histological and molecular follow-up was performed on 14 months (figure 2). 
Results have shown, without MSC treatment, an initiation of CRC at 6 months, with chronic inflammation, hypoxia, hematuria, disorganization of the urothelium and fibrosis. Analysis of urinary parameters has revealed hematuria increasing with time. Transcriptomic analysis indicates chronic inflammation (IL1 $\beta$, CCL2, IL6) and hypoxia (HIF1 $\alpha$ ). Histological observations reveal a disorganization of the urothelium with loss of superficial cells and fibrosis (figure 3). Study is in progress to evaluate whether MSC treatment could limite fibrogenesis by inhibiting the inflammatory pathways and increasing angiogenesis, in our model CRC preclinical model. Our results will provide data regarding the anti-fibrotic potential of MSCs and could support their use in the treatment of CRC.

Ringden O, Uzunel M, Sundberg B, et al. Tissue repair using allogeneic mesenchymal stem cells for hemorrhagic cystitis, pneumomediastinum and perforated colon. Leukemia 2007: 21: 22712276.

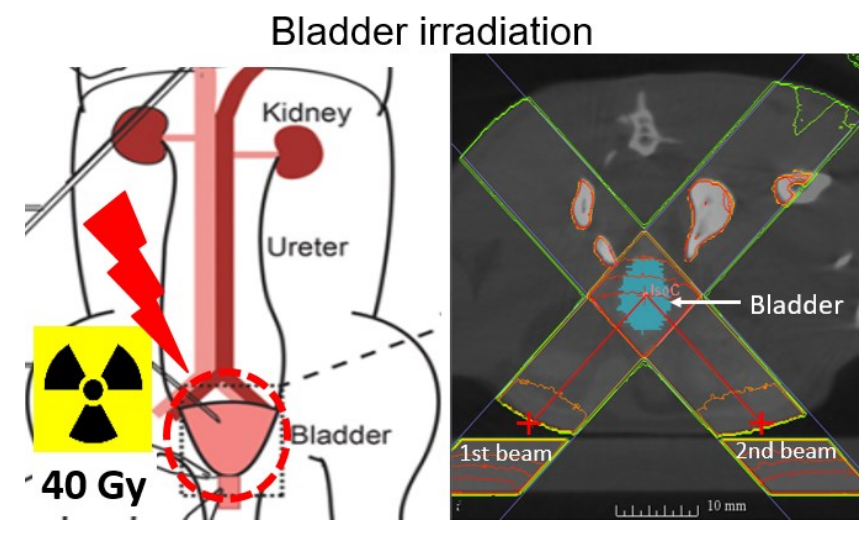

Figure 1: Bladder irradiation pattern

Legend: Schema of rat bladder irradiation (A). Image of the treatment plan obtained using Small Animal Radiation Research Platform (SARRP), the bladder is irradiated in its entirety with two beams in order to maximize the dose received by bladder and minimize the dose of the surrounding tissues (B)

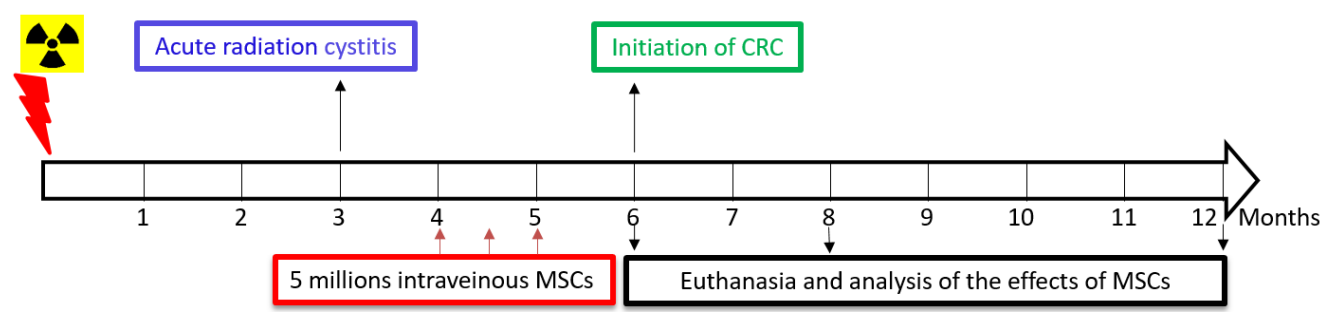

Figure 2: CRC Treatment of CRC by MSCs

Representation of CRC treatment by MSCs. 5 millions of MSCs are intravenously injected at 4 months post irradiation, 3 time, every 2 weeks to potentiate their effects. The effects of MSCs are studied at 6, 8 and 12 months after irradiation. 
For $40 \mathrm{~Gy}$, at 6 months:

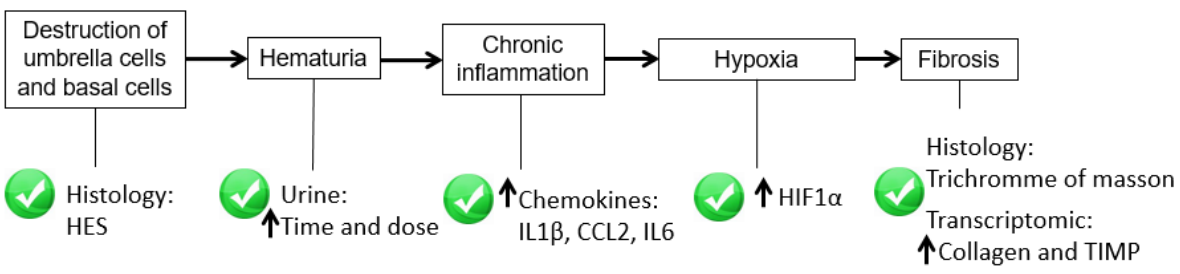

Figure 3: Summary of main results

Summary of the main results. After irradiation of bladder at 40 gray (single dose), we observed a degradation of urothelium structure accompanied by hematuria. At 6 months post-irradiation, the inflammation was chronic and accompanied by hypoxia resulting in the initiation of fibrosis. 